\title{
LANGUAGE ACQUISITION: CLASSROOM LANGUAGE ACQUISITION FOR PRESCHOOL STUDENTS
}

\author{
Rosdiana \\ Department of English Education, Faculty of Language and Art, University of Indraprasta PGRI \\ Jalan Nangka No. 58C Tanjung Barat, Jagakarsa, Jakarta Selatan 12530 \\ rosdianasidik.rs@gmail.com
}

\begin{abstract}
This paper explained about the language acquisition of the preschool students. The language acquisition involved the mini research by using qualitative approach. The researcher did observation to TK. A Bintang Semesta and did case study to know the acquisition of classroom language in that school. The researcher also identified the process of children' language acquisition and also identified the process of acquisition. In this paper also explain the relation of data in the field with expert opinion about language acquisition.
\end{abstract}

Key words: language acquisition, classroom language, preschool students

\begin{abstract}
ABSTRAK
Artikel ini membahas mengenai pemerolehan bahasa pada siswa prasekolah. Hasil penelitian ini didapatkan dari penelitian kecil dengan menggunakan pedekatan kualiatatif. Penulis melakukan observasi pada TK. A Bintang Semesta dan melakukan studi kasus untuk mengetahui pemerolehan bahasa kelas pada sekolah tersebut. Penulis juga mengidentifikasi proses anakanak dalam pemerolehan bahasa dan proses pemerolehan bahasa itu sendiri. Artikel ini juga menjelaskan hubugan antara data yang ada dilapangan dengan pendapat para ahli mengenai pemerolehan bahasa.
\end{abstract}

Kata kunci: pemerolehan bahasa, bahasa kelas, siswa prasekolah 


\section{INTRODUCTION}

Human's language is like winged bird. Language cannot be separated from the nature of the human, because it is human device to communicate each other. From the statement above, it seems that human without language like bird without wings, because wigs are characterizes bird, and language is characterizes human.

The terminology of acquisition is used for comprehend of language that is done by children naturally when they learn their mother tongue (native language). This terminology can be distinguished from learning. Learning is done by using formal education, and acquisition is done by natural.

Language acquisition is process of human to get ability to capture, produce, and use words to comprehend and communicate. This capacity is accommodating some skills and ability like syntactic, phonetic, and wide vocabulary. Language is comprehended can be vocal like spoken or manually like sign language. Language acquisition usually refers to first language that studies children's language to their mother tongue, not their second language (Gleason \& Ratner, 1998).

Modern linguistic and psycholinguistic are able to explain to us about how and what can be learned by children. They can practice by using communication competence. However, there are some questions that have been answered, which are: how do children acquire the language? How do children decide meaning of word? Or how produce speech structure that they have never heard before? The Researchers do not agree on why children learn languages; whether children learn the language because the adults teach the language to them? Or it is genetically programmed to accept the language? Do they learn complex grammar because it is available? Or they learn the language because they need it to communicate? Psycholinguistic development is a science which deals with the child's language acquisition.

Meaning of language acquisition in children is very important for the development of communicative ability. In communication activities, domiciled meaning and role in the preparation and understanding of the message. It is based on that in essence, the purpose of language is to communicate meaning and linguistic competence essentially accompanied semantic competence communicative competence in order to be realized. At the age of approximately five years the process of language development of children already resembles the adult language, both aspects of the sound, the words, the syntax, and the organization of discourse. However, the process of development of meaning in language children are not automatically in line with the development aspects of linguistic structure (Gleason \& Ratner, 1998).

Children have a golden age when they were a child. Where a child is learning, they were born endowed with a potential basis for speaking in the form of speech synthesizers biological and coordination abilities and speech production therein. Mental and biological capabilities serve as the foundation for language development. It's the kind of description by Djardowijojo (2000) language development of a child is not only affected by neurological development, but also by their biological development. A study shows that for ages 0-11 years old, the child's ability to absorb (pronounce and understand the meaning of the word) is quite remarkable, whereas the period after that, the development of capabilities back to the 
rhythm and tempo that normal (not too fast). The living and interacting with the community in a sustainable society bombarded with language. Mukalel (2006) stated that but the early stages of language development do not seem to be influenced by what is happening around them.

Classroom language is the language used in the classroom as a form of interaction between students and teachers. Classroom Language is an expression - an expression used when it was first used in the classroom. Sutriso (2016) affirms that with so children experience acquiring languages other than ordinary language - a day at home, and they know that they will use language classroom at school when interacting with teachers and other students.

\section{METHOD}

On this mini research, the author had the opportunity to conduct a case study on TK. A Bintang Semesta Depok on child language acquisition is the acquisition of classroom language or languages used in class as one introduction in the classroom for teachers and students in the school's preschool. A qualitative approach with case study method in kindergarten Bintang Semesta. The activities are observations in the classroom, following any activity was undertaken by the students naturally and conduct interviews with the responsible teacher in the classroom about how the situation and the circumstances during the learning process takes place. From the above explanation, this small study aimed to find out how the process of language acquisition kindergarten Bintang Semesta.

\section{RESULTS AND DISCUSSION}

Based on the results of observations was have done by the author. The author knows that children in Bintang Semesta Kindergarten trained to get used to doing those things taught by teacher. Teachers use two languages, Bahasa and foreign languages which is English that they use as a form of curriculum of bilingual program. Teachers try to repeat what they told that children unwittingly will understand the word or phrase. In the following table, some examples of classroom language are used:

Table 1

Classroom Language at Bintang Semesta Kindergarten

\begin{tabular}{|c|c|}
\hline English & Bahasa \\
\hline $\begin{array}{lr}\text { Good } & \text { morning my } \\
\text { dear } & \text { students/ } \\
\text { class } & \end{array}$ & $\begin{array}{l}\text { Selamat pagi } \\
\text { anak-anak }\end{array}$ \\
\hline $\begin{array}{ll}\text { Good } & \text { morning } \\
\text { Miss.... } & \end{array}$ & $\begin{array}{l}\text { Selamat pagi } \\
\text { Miss... }\end{array}$ \\
\hline $\begin{array}{l}\text { How are you } \\
\text { today? }\end{array}$ & $\begin{array}{l}\text { Bagaimana } \\
\text { kabarnya hari } \\
\text { ini? }\end{array}$ \\
\hline Hallc & $\begin{array}{l}\text { Halo anak - } \\
\text { anak }\end{array}$ \\
\hline Pay attention & Penuh perhatian \\
\hline Clean up please & $\begin{array}{l}\text { Rapihkan } \\
\text { kembali }\end{array}$ \\
\hline $\begin{array}{l}\text { Are you happy } \\
\text { today? }\end{array}$ & $\begin{array}{l}\text { Senangkah } \\
\text { belajar hari ini? }\end{array}$ \\
\hline $\begin{array}{l}\text { Thank you Miss, } \\
\text { see you later }\end{array}$ & $\begin{array}{lr}\text { Terima } & \text { kasih } \\
\text { Miss, } & \text { sampai } \\
\text { jumpa lagi. }\end{array}$ \\
\hline
\end{tabular}

Learning a language is a process of internalization system. This process is very clear and systematic reaffirmed by Noam Chomsky in the theory of generative transformation language. Noam Chomsky, a linguist 'inventor' theory of transformational-generative grammar of the language, he believes that in the child there is a kind of "tool" 
used as a means of acquiring a language. Since the birth of children own disposition, talent (innate capacity), which form Language Acquisition Devices (LAD) to acquire language naturally. Their innate capacity or the LAD according to Chomsky can be used to explain what is going on in the child miraculously able to learn the language quickly. In contrast to the tabula rasa theory which states that the baby's brain at the time of birth likened blank paper, which will be written by those experiences. Skinner said the language born of the form S - R, stimulus response. Mukalel (2006) in the other hand, Piaget's theory of cognitive development that includes a discussion of language, which became known as the hypothesis of cognitive universals.

Chomsky, says that if we learn the language then in essence we are studying the essence of man, which makes the uniqueness of the man himself. Humans were designed for walking, but are not taught to be run. Similarly, in speaking, no one can be taught the language since man is created to speak. In the sense that in fact humans will inevitably speak so she did not acquire the language.

Chomsky's theory connection with the situation of Bintang Semesta Kindergarten, the children have the ability to understand language because it is equipped with a device in his brain, but the teachers stimulate the children by saying the language classroom repeatedly again so that children understand and gain an understanding of the meaning of every word the teacher without them knowing it. When would mengajakan students Classroom English expressions, you should teach them the same way when you teach vocabulary (vocabulary) to show your objects or things that seem real to them. This means that by demonstrating the real situations in practice these expressions with the response or responses of students in communication (Sutrisno, 2016).

Furthermore, Chomsky assumes that language users understand the structure of language that makes a person can create new sentences are countless and make someone understand sentences. During the first language acquisition, Chomsky says there are two processes that occur when a child obtain a first language. The process in question is the competence and performance process. These processes are two different processes, competence is intuitive knowledge owned by an individual on his mother tongue (native languange). This linguistic intuition does not just exist, but developed in line with the child's growth, while performance is something produced by competency. Competence is the mastery of grammar (phonology, morphology, syntax and semantics) naturally. This competence is taken by every child from birth. Although innate, require competency coaching so that children have a performance in the language. Performance is the child's ability to use language to communicate. The performance consists of two processes, namely the process of understanding and the process of issuing sentences. The process of understanding involves the ability to observe or perceive the sentences were heard, while the publishing process involves the ability to produce their own sentences.

In that school, teachers dig competence to produce performance of children in the language. In the end, the child has the capacity to use the language classroom. Because of the acquisition is that they get from their teachers, they imitate what the teacher says and teachers kept saying over and over again so the children understand without having taught directly.

In other words, the child is already 
able to produce a sentence that regardless of classroom language or not, but the function of teachers and school environment here is very important and influential. In line with this Mukalel (2006) states several psycholinguistic factors in language acquisition are: intelligence, resourcefullness, creative, and motivation.

First, intelligence, it is defined as the 'ability to learn', that is, the ability to organize, receive/understand, unite/combine and arrange the components that take into account the learning process in school activities. Intelligence as 'the ability to carry on abstract thinking'. Intelligence is always associated with anything hat is common (abstraction), drafting, and theorize. Behavior definition of intelligence is read as 'adjustment or alignment of the individual to the environment'.

Intelligence functions in human beings as stewards of emotion. Spearman appropriate, 'in general the intelligence is the mental world'. Thrustum believe that intelligence is not a factor, but the ability of the complex, the ability of such number, verbal, reasoning, and memory settings. According Peaget, there is a functional and structural intelligence determines the way we do things. Flavel argued intelligensi in some components, they are a motor sensory development, the period preoperational, concrete operational period, and formal operational period.

Moreover, resourcefullness is another psycholinguistics factor, is able to adapt to the environment, the relatives, the ability of the organization and administration: A person considered to be resourceful when it can speak well. A person who can utilize the language skills to control and change the social environment for the better. Being able to use the language efficiently professional.
A person who is able to optimize a person's intelligence and did not have a problem to master several languages.

Third, creative is doing things in a new way and unusual: a creative child tend to be active and bring surprise to parents, directing one's thoughts and perform a set of goals, Creative people are independent thinkers; they do not agree with the system and the existing value. Lastly, motivation is the force that drives the achievement of objectives. The higher the motivation, the greater the enthusiasm and energy to achieve the goal.

Psycholinguistic factors in language acquisition is said by Mukalel (2006) that the factor of intelligence, resourcefulness factors, creative factors and motivational factors influence child language acquisition. Every child has the language skills is extraordinary from birth, although they were able to communicate only through gestures, crying, whining.

Language is said to be a uniqueness that characterizes and distinguishes humans from other living beings. This statement does not mean that only people who have communication devices. The animal is called not speak but can still communicate. Ravings parrot that can mimic human speech; command 'sit' or 'chase' is understood the dog; monkey ability to understand human speech commands; rhythmic singing of birds; tempo sound that echoed bees; voices issued whale; all these are examples of animal communication devices. This tool is not necessarily called language although it resembles the language. Examples of communication devices above does not bear the designation language because it does not fulfill the prerequisites of a language such as: message exchange element of the speaker on the listener and vice versa; 
the feedback from the speaker; meaningfulness and discrimination unit vocabulary; their cultural transmission processes underlying speech; the emergence of creativity and ability patterning unit of language; control purposes and transitional talk turn to talk, as well as the use of the phrase is not a literal meaning.

From the explanation above, it can be concluded that the acquisition of language in this classroom language in the Bintang Semesta Kindergarten was going very natural and good. Teachers act properly taught by repeating what they teach so that children naturally understand the intention of greeting the teacher unconsciously they basically are learning. In the end the child accustomed to using language classroom a day - a day in the classroom and it came to pass on the language acquisition students at kindergarten.

\section{CONCLUSION}

First language acquisition closely related to the social development of children and thereby also closely connected with the formation of social identity. Learn the first language is one of the holistic developments of children becoming a full member of a community. In general, children acquire language skills through language sounds he heard around him or ruled accidental. Proficiency evolves continuously in accordance with the development of intelligence and socio-cultural backgrounds that make it up. It also happens to students of Bintang Semesta
Kindegarten, language acquisition in this case the language classroom at Bintang Semesta Kindegarten was going very natural and good. Teachers act properly taught by repeating - repeating what they teach so that children naturally understand the intention of greeting the teacher unconsciously they basically are learning.

Understand the speech of others is the first element that must be controlled by humans in the language. Similarly, humans only produce speech when he learns the rules that must be followed acquired since childhood. The question is, why the acquisition of different languages in adulthood than acquisitionrelated since the child is still small, and the structure and organization of the human brain.

\section{REFERENCES}

Dardjowidjojo,

S. (2003). Psikolinguistik (Pengantar Pemahaman Bahasa Manusia). Jakarta: Unika Atma Jaya.

Gleason \& Ratner. (1998). Psycolinguistics (Second Edition). United State: Harcourt Brace College Publishers.

Mukalel, J. C. (2003). Psychology of Language Learning. New Delhi: Discovering Publishing House.

Sutrisno, B. (2016). Classroom English Expressions (Billingual). Retrieved from www.mrbejo.com, Tuesday June 14, 2016. 